\title{
Form And Meaning Of Batak Toba House
}

\author{
Ronald Hasudungan Irianto Sitindjak \\ Department of Interior Design \\ Petra Christian University \\ Surabaya, Indonesia ronald_his@petra.ac.id
}

\author{
Laksmi Kusuma Wardani \\ Department of Interior Design \\ Petra Christian University \\ Surabaya, Indonesia \\ laksmi@petra.ac.id
}

\author{
Poppy F. Nilasari \\ Department of Interior Design \\ Petra Christian University \\ Surabaya, Indonesia popie@petra.ac.id
}

\begin{abstract}
The Batak tribe is a large tribe of Tapanuli region in North Sumatera. This tribe consists of six secondary tribes, the largest one being the Batak Toba tribe. The traditional architecture of their past dwellings were called Rumah Batak Toba. They vary in form and can be differentiated from one another by their functional use and building elements such as walls, stairs, entrance doors and ornamentation. Behind every different form, there was always a value or meaning. Hence the form and meaning of the Batak Toba house could be interesting objects of research. This research used random samples of Batak Toba houses in the regions of Samosir and Tobasa of the North Sumatera province, in which their inhabitants are mainly from the Batak Toba tribe. The research adopted Erwin Panofsky's method of iconography that was conducted through two stages: pre-iconography and iconography. This method was used to describe the form and analyze the hidden meaning behind the architectural and interior forms of the Batak Toba house. Based on the analysis of data, it was found that the meanings behind the architectural and interior forms of the Batak Toba house cannot be separated from the beliefs of the Batak Toba tribe regarding the harmony between the human life and the universe (macrocosm and microcosm). A house was the embodiment of the process of human life from birth to death. It represented the ideas and views of family values, togetherness and social life as well as a representation of the values of physical protection and safety. Moreover, it was a spiritual symbol of life views, norms, beliefs, philosophical values, and local wisdom of the Batak Toba people.
\end{abstract}

Keywords : Form, Meaning, Architecture, Interior, House, Batak Toba

\section{INTRODUCTION}

In the past, traditional houses were the most determining environment to meet the needs of human life. The house represented all the patterns of life activities that were fostered for generations. It represented the expressions of its inhabitants, their cultural values, conceptions, beliefs, norms, customs, and various knowledge in seeking experience for calmness, tranquillity, and equanimity. The house communicated values about human growth to become a better being. The beauty of its form represented the sociocultural wisdom of the society that can be studied more deeply. Through a long process, the house changes along with increased knowledge from simplicity to more levels of complexity[1].

The preservation of traditional houses in Indonesia cannot be separated from the influence of modern culture today. Changes do occur as a result of increasingly complex needs. The meaning of its interior is translated as an adjustment to human activities that develop in order to adapt to changes in time. However, today there are still many traditional houses that are still maintained in authenticity, where each part of the house has a different name and meaning. Analyzing the meaning of space needs to pay attention to the attitudes of life, beliefs, customs, mindset and behavior of society, because a building accommodates the socio-cultural life reality of society. Hence, the house needs to be maintained, preserved and studied as a living science, which continues to grow, develop, and survive as the wisdom of the nation's culture.

The Batak tribe is one of the major tribes from the Tapanuli region in North Sumatra. This tribe has six subtribes, in which the largest is the Batak Toba [2]. The traditional house where the Batak Toba people lived in the past is called Ruma / Jabu. Their types and forms vary and can be distinguished based on their functions and based on the design of building elements, such as the forms of walls, stairs and entrances, as well as the existence of ornamentations. Behind these forms there are always hidden values and meanings based on the society's cosmology. This makes the traditional Batak Toba house interesting to study, due to the meanings attached to it.

\section{LITERATURE REVIEW}

\section{A. Beliefs of Batak Toba People}

The analysis of the meaning of traditional buildings will always be related to the beliefs and life views of the local community regarding the formation of the universe. The Batak Toba people believed that the universe was created and controlled by Debata Mulajadi na Bolon (God Almighty), which manifests itself in three Debata or Debata na Tolu (three universe arrangements) namely Tuan Bubi na Bolon who rules over the upper realm (Banua Ginjang), Tuan Silaon na Bolon, who ruled the central realm (Banua Tonga), and Tuan Pane na Bolon, who ruled the lower realm (Banua Toru). The mythology about the belief in the unity of the cosmos (universe) of the three banua is a symbol of the tranquillity of the universe. The upper banua is the place of the Master of Nature (God Almighty), the middle banua is the middle place for human life or mortal nature, and the lower banua is the place of evil spirits (nature of darkness) [3].

\section{B. The Batak Traditional House}

Traditional houses grow and develop together along with the development of a tribe. Hence, traditional houses are one of the identities of a tribe or community that supports it. They reflect the personality of traditional communities and represents the integrated ideal, social and material form a culture [4].

According to Germain \& van der Goes [5], a traditional Batak house is known for its extraordinary roof section and its surface that was beautifully and meticulously decorated. The various types of Batak buildings include residences, meeting houses, barns, rice pounding huts, and 
funeral homes. All buildings were rectangular in shape with a staged floor supported by large pillars and roofs at the top. The roof was made from coconut palm fiber, a triangular wall, and the roof projects outward. Building materials were made of wood and other natural materials. Without using nails, separate elements were combined with tanggam and lumpang or tied up with palm fibers. The pillars of the house rest on a stone foundation and the space beneath the staged floors were covered and used as a buffalo cage. In the past, a Batak house was occupied by several families in which physical placements in the house showed their social relations with the main owner. The family units were grouped around the fireplace and the family room was divided at night by hanging mats or fabric that gives personal freedom. Beyond that there was no division of space.

Another study in the form of a dissertation by Widodo [6] examined the aesthetic expressions of Silawuh Jabu Karo building typical of Batak Karo ethnic and Ruma Toba of Batak Toba ethnicity. His research focused on finding a size comparison system, through various interpretations of the objective cultural values of the Batak people of the past. On the other hand, Hanan [7] in the Procedia-Social and Behavioral Science Journal, wrote about the influence of modernization and cultural transformation on the expansion of the Batak Toba house in Siallagan village.

\section{PROBLEM STATEMENT}

The traditional Toba Batak house is a national asset and has the potential to strengthen the identity of the Indonesian nation which is rich in traditional culture. The value of the house lies not only on its beautiful form, but also the philosophy behind it. Many traditional Batak Toba buildings today have changed in form and function due to the influence of modernity and the changing lifestyle of its people. Whereas in traditional Batak Toba houses there are many ideas, concepts, and a wealth of cultural values that need to be preserved. For this reason, the objective of this research is to observe and discover the meanings of the traditional Batak Toba house, so that it can be used as a reference for the preservation of the local wisdom of the nation's culture.

\section{METHODOLOGY}

This study discusses the traditional Batak Toba house in Samosir Regency, which is the area of origin of the Batak Toba people. Determination of the research sample took into account the criteria of traditional houses that are still physically intact, and still functions as a residential space or has been converted for use of other functions, such as supporting traditional art performances and conservation. The study took samples from traditional houses in Huta Bolon Samosir.

This research focuses on the study of the meaning of architectural forms and the interior of traditional Batak Toba houses. The discovery of meaning uses the Panofsky iconology method [8], through three consecutive stages, namely:

1. Pre-iconographic stage, to find textual (factual and expression) meaning
2. Iconographic stage, to find contextual meaning (extrinsic), and

3. Iconological stage, to find symbolic (intrinsic) ways

The data were collected through literature review, especially in relation to the history of the formation of traditional houses, the development of building forms and the socio-cultural development along with the cultural values and community beliefs. Physical data on the conditions of the house were obtained through field observations and visual documentation. The interviews were conducted with expert speakers who mastered the values of local culture, in particular, the local stakeholders, cultural observers, and their supporting communities.

\section{PRE-ICONOGRAPHIC DESCRIPTION AND ICONIC ANALYSIS OF TRADITIONAL TOBA BATAK HOUSES}

\section{A. Building Site}

Traditional Toba Batak houses are generally situated in a village (Huta) in a clustered pattern. The group of buildings in a huta consists of two rows. The first row consisted of residential houses (Ruma/Jabu), while the opposite row consisted of a granary (Sopo) which was a place to store rice. The open area between the buildings is called Alaman.
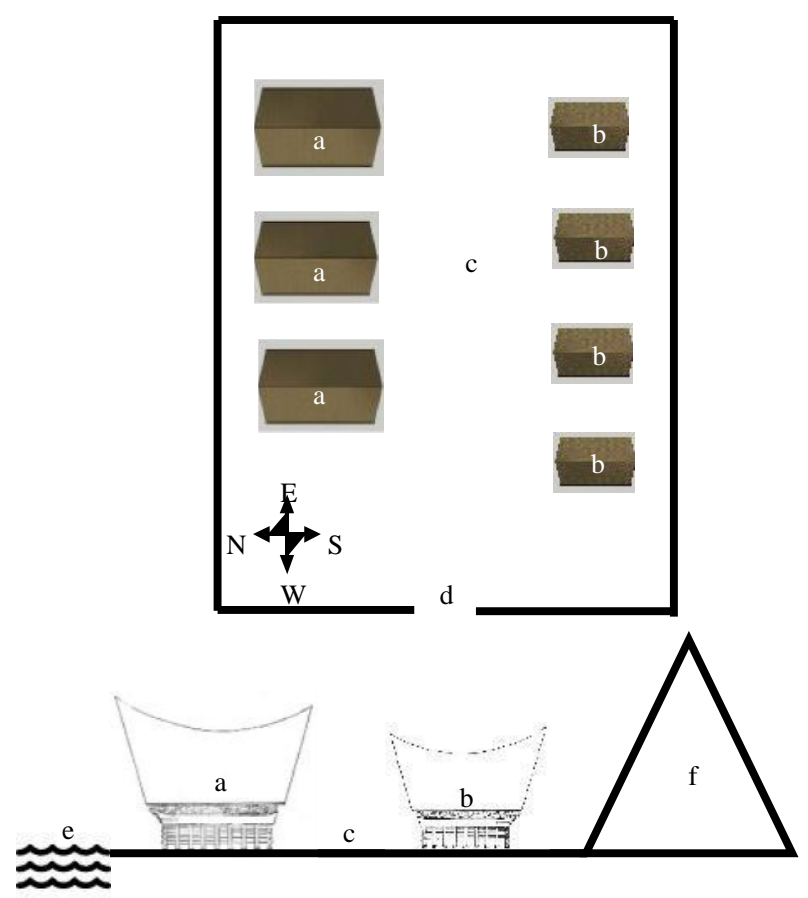

Figure. 1. Huta Bolon Village layout (top); side view of the arrangement lakeruma/jabu-alaman- sopo-mountain (bottom). (a) Ruma/jabu, (b) Sopo; (c) Alaman; (d) Gate/Harbangan; (e) Lake; (f) Mountain (Ronald, 2018)

Ruma/Jabu row faces south while the sopo faces north. On the south side, there is a row of mountains, while in the north there is a lake. The direction facing Ruma / Jabu faces the plateau or mountain in the south, meaning a respect and worship of the Supreme Creator (Debata Mulajadi Na Bolon) who dwells in and is the ruler of the Upper World. In addition, the Batak Toba people also believed that the spirits of ancestors who had passed away 
inhabited high places like the mountains. The direction facing the Batak Toba house was made facing the mountain. Hence, the direction facing the Ruma Batak Toba building conotes a meaning that is related to the people's beliefs and cosmology.

\section{B. Architectural Form of Batak Toba Traditional House}

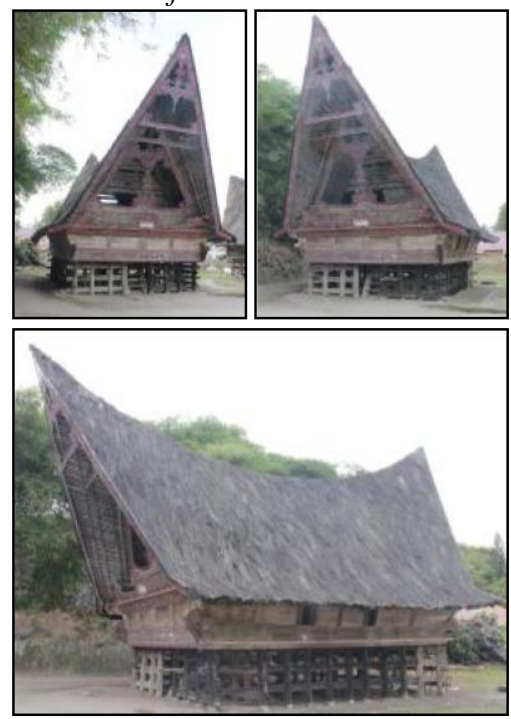

Figure. 2. Ruma Batak Toba in Hutabolon, Simanindo, Samosir, South Sumatera (Ronald, 2018)

The basic form of the traditional Batak Toba house (Ruma Batak Toba) from the front view, is a combination of three basic parts, namely the rectangular plane (the bottom), the trapezoidal plane (the middle) and the triangular plane (the top). The appearance of the right side is not much different from the front side, except at the top. The bottom area forms a rectangular plane and the middle part is a trapezoidal shape. While the upper plane is in the form of a horse saddle. The pointed corner of the front area is more protruding to the front, while the pointed angle of the back rises up or higher. The appearance of the upper side produces a hexagonal plane in which the sides are not in parallel. The front and the back form an equal triangular plane, but the front is more protruding than the back. While the middle part forms a rectangular field. The lower part serves as the building foundation, the middle part functions as a the building's body, while the upper part is the building roof.

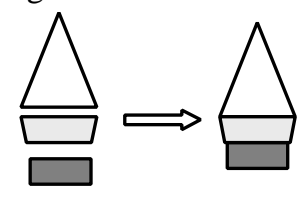

a
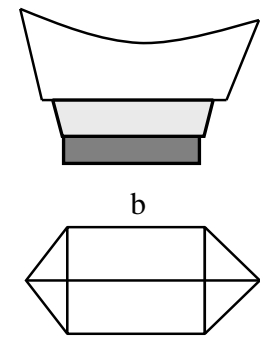

$\mathrm{c}$

Figure. 3. Form of Front View (a), Right View(b) and Upper View (c) of Ruma Batak Toba (Ronald, 2018)

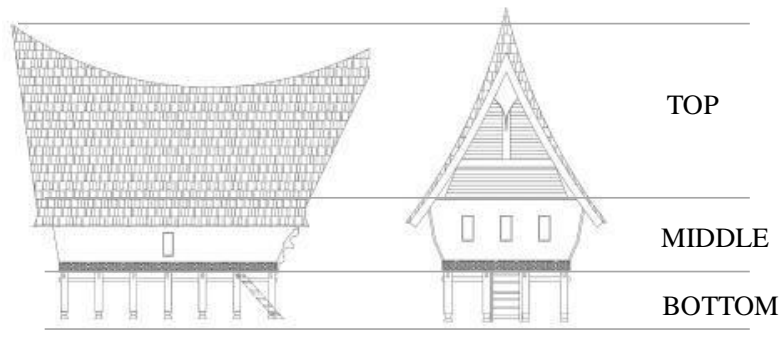

Figure. 4. Level Distribution of Ruma Batak Toba (Ronald, 2018)

The form of Batak Toba house architecture vertically, consists of three parts containing cosmological meanings. Ruma Batak Toba is the representation of the microcosm and macrocosm according to the Batak Toba people.

\section{Microcosm of Ruma Batak Toba}

The top is the roof. Its form is like a big and soaring saddle model. The front porch is in the form of a balcony, with the roof support structure tilting outward, and there are decorative pieces (gorga) on the front of the building which symbolizes the social position of the owner. The rear roof is higher than the front of the roof, and this means that the next offspring must have a higher life achievement than the previous one. In other words, the next child or descendant must be more successful than his parents.

The middle part of the house is the front, side and back walls, which are supported by straight and a high pillar, called ninggor, and are assisted by other supporting woods. This pillar is a symbol of honesty and justice. The bottom of the house is the foundation, made with a rectangular formation, combined with strong columns and walls, and with stairs as access to enter the house. The meaning of this foundation is to work together to carry a heavy burden.

\section{Macrocosm Ruma Batak Toba}

The house is meaningful as an illustration of the universe in which Debata Mulajadi na Bolon (God Almighty) can manifest into three Debata or Debata na Tolu (three universe arrangements). The upper part of the house is the symbol of the upper world (Banua Ginjang) which is controlled by Tuan Bubi na Bolon, as the place of the Creator and the spirits of the ancestors as the rulers of the afterlife. The central part of the house symbolizes the middle world (Banua Tonga) which is controlled by Tuan Silaon na Bolon, as a place of human life or mortal nature. The bottom / under the house is a symbol of the underworld (Вапиа Toru) which is controlled by Tuan Pane na Bolon, as the place of evil spirits (the realm of darkness).

The concept of banua, especially Banua Ginjang, as mentioned by Sihombing [9], does not refer to heaven and Bапиа Toru also does not refer to hell. The trinity concept of Banua has the same value to one another, only its inhabitants are different. The mythology regarding the unity of the cosmos (universe) of the three banua is a symbol of tranquillity of the universe. From the iconographic analysis, Ruma Batak Toba was found to represent a microcosm (three levels of space) which symbolizes the macrocosm (three banua). The harmony 
between these three parts was believed to bring peace, blessing, and prosperity [3].

TABLE I. COSMOLOGICAL MEANING OF RUMA BATAK TOBA

\begin{tabular}{|c|c|c|}
\hline $\begin{array}{c}\text { Area of } \\
\text { Ruma }\end{array}$ & $\begin{array}{c}\text { Microcosmic } \\
\text { meaning }\end{array}$ & Macrocosmic meaning \\
\hline Roof & $\begin{array}{c}\text { Success, hopes } \\
\text { and dreams }\end{array}$ & $\begin{array}{l}\text { The Symbol of the Upper World (Banua } \\
\text { Ginjang), where the Creator (Mula Jadi } \\
\text { Nabolon) and the spirits of the ancestors } \\
\text { as ruler of the afterlife live. }\end{array}$ \\
\hline $\begin{array}{l}\text { Wall \& } \\
\text { Floor }\end{array}$ & $\begin{array}{l}\text { Truth and } \\
\text { Justice }\end{array}$ & $\begin{array}{l}\text { The symbol of Middle World (Banua } \\
\text { Tonga), where humans and all other } \\
\text { living creatures live in their daily lives. }\end{array}$ \\
\hline Underfloor & Cooperation & $\begin{array}{l}\text { Symbol of the Underworld (Banиa } \\
\text { Toru), where the evil rulers live and die. } \\
\text { Described as a dirty, bad place. }\end{array}$ \\
\hline
\end{tabular}

\section{E. Interior Spatial Organization}

The interior of the house consists of one rectangular room, with towering ceilings that blend with the roof function, and have a balcony on the front and back. The interior of the house is generally dark because the windows (padiloan) of the house are small and few in number. There are no rooms separated by walls, but there are cultural rules for the division of spaces in each corner of the house, namely: Jabu Bona, Jabu Soding, Jabu Suhat, and Jabu Tampar Piring. The division is not based on wall division but based on the family status of the occupants. The room functions as a place to live and sleep, as well as a place to store daily items and utensils.

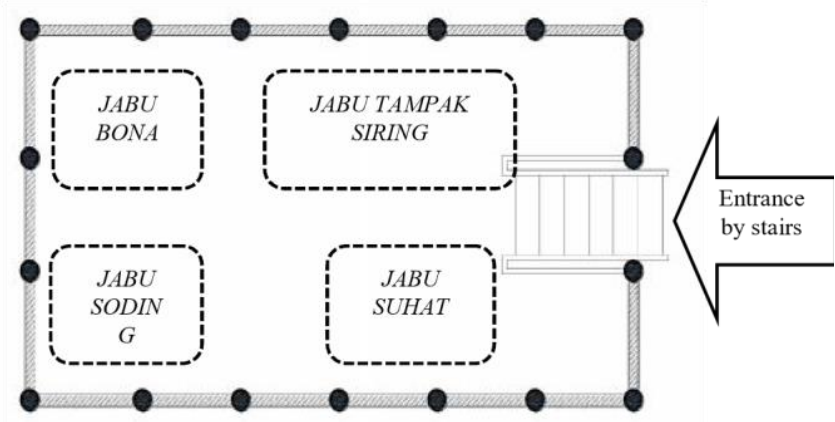

Figure. 5. Interior Layout of Ruma Batak Toba

Jabu Bona is in the back right corner of the house entrance. This part is occupied by the host family. Jabu Soding is located in the back left corner of the house entrance. This part is occupied by the host's daughter's family, if they do not have their own home. If there is no married daughter, the area is used as a sleeping space for children who are not married. Jabu Suhat is located in the front left corner of the entrance. This section is for the eldest child who has a family. Jabu Tampar Piring is in the right front corner of the entrance. This section is prepared for guests. The interior of the Ruma Batak Toba represent values of transparency, openness and community in the life of the Batak Toba people.

Although they do not have rooms, and occupy open spaces communally, privacy is still considered. Privacy occurs partly due to the dark conditions of the room, due to the lack of openings that can let natural lighting to enter. In addition, privacy is also created through the enactment of laws and rules, which make the residents of the house unable to behave indiscriminately inside the house. This is why the Ruma Batak Toba is called also called "jabu na marampang na marjual", which means a house that has laws, rules and criteria, so that one may not behave carelessly in it.

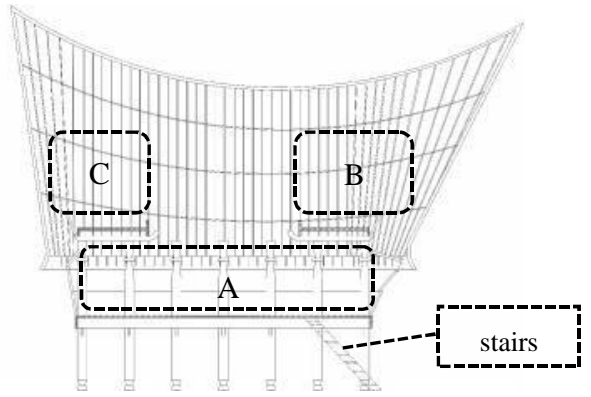

Figure. 6. Section View of Ruma Batak Toba. (A) Interior; (B) Front Balcony; (C) Back Balcony (Ronald, 2018)

Access to enter the house is done via stairs. Stairs are numbered odd: 5,7 or 9 . They are located between the front column and the inner column, while the door is on the floor. This means that every person and guest who enters the house must submit to the laws and rules of the house before entry. In addition, by Access to enter the house is done via stairs. Stairs are numbered entering downwards, it becomes a symbol of respect for the host.

On the roof of the front and back are, there is a small balcony. Between the front balcony and the back balcony there are large transverse beams, to place offerings to the spirits of ancestors. The front balcony is usually used for gondang musicians (pargonsi) to accompany dancing events (manortor), both inside and outside the home. This roof area is a sacred area in the interior of the house.

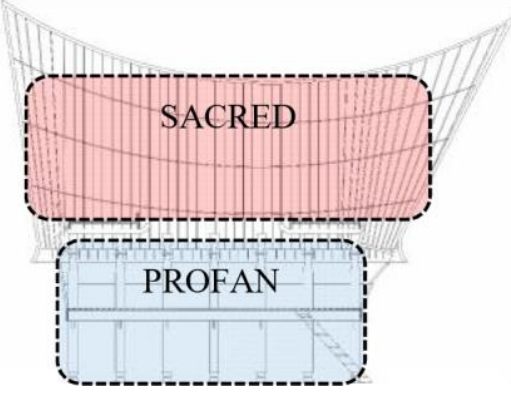

Figure. 7. Section View of Ruma Batak Toba (sacred-profane scheme)

Therefore, in the interior of the Ruma Batak Toba, the horizontal spatial organization covey meanings of transparency, openess and community. However, privacy still exists not through physical barriers but rather mental barriers through various customary laws, rules and criteria. Meanwhile, the vertical spatial organization represents the macrocosm, connoting that the uppermost area is the sacred area while the area below it is profane.

\section{ICONOLOGICAL INTERPRETATION OF BATAK TOBA TRADITIONAL HOUSE}

A. The House as a Family Place

Houses in the Batak Toba language are referred to as "Ruma, Jabu, Bagas, Sibagandingtua". Ruma, Jabu and Bagas not only refer to space, spatial matters or physical buildings alone, but also refer to families or households, namely "how-to-live-in-family". In other words, Ruma, Jabu and Bagas have deeper meanings because of their 
close relationship with family. Ruma is related to spiritual aspects, while $J a b u$ is related to function, morals and manners. Hence, according to the Batak Toba people, the house is not just a physical object, but also matters related to family life.

\section{B. The House as a Source of Blessings}

The house is not only a place of physical shelter and a physical place to live, but also a source and the gathering of blessings for those who live in it. Starting from the construction of the house all the demands and prerequisites according to the society's traditional customs must be taken seriously. Starting from the preparation of the hermitage of the house, the process of supplying all timber for building materials (logging, wood harvesting and use), preparation of the main columns, installation of walls, installation of roofs, up to the inauguration process, and entering a new house. If all the demands and prerequisites are met properly and correctly, then the house can be a blessing for its inhabitants.

\section{CONCLUSION}

The traditional house for the Batak Toba people is not just a place to live, but also a representation and description of beliefs /faith, outlook in life, hopes and ideals. The house is also as (1) a description of cosmology, (2) place of family, and (3) source of blessing.

The traditional Batak Toba house is a national cultural asset that contains symbolic meanings about the wisdom of the cultural and social life of the Batak Toba people. These symbolic meanings need to be reapplied in the houses of the Batak Toba people. The shape of the house can change, but the symbolic values in it must be preserved today as a wealth of local ideas and values.

With the ongoing process of modern development which results in socio-cultural changes in the originals regions of the Batak Toba people, the function of traditional houses today have also undergone changes. There is a change in form and there is also a change in function from once a private area into a public space due to the increase of tourism purposes. In addition, the economical demands have brought changes to the organization of space in traditional homes to be more efficient and practical. The space previously used for domestic interests of developing families today have adapted economic-oriented activities which have an impact on changes in the function and meaning of space.

For this reason, it is necessary to study these values of cultural wisdom contained in the traditional houses so that the society in general can understand the changes in the values of today's society with wisdom, so as to minimize negative effects both on the symbolic, social, and practical functions of occupant's activities.

\section{ACKNOWLEDGEMENT}

The authors would like to thank the Directorate of Research and Community Service, Ministry of Research, Technology and Higher Education, which has provided funding for research.

\section{REFERENCES}

[1] L.K. Wardani, "Perubahan Desain Rumah Tinggal Jawa Menjadi Ruang Publik Terbatas". Dimensi Interior, vol. 5, no. 2, pp.98-108,

2007.

[2] P. Bangun, "Kebudayaan Batak", in Manusia dan Kebudayaan di Indonesia, Koentjaraningrat, Ed. Jakarta: Djambatan, 2012.

[3] R. Sitindjak, L.K. Wardani \& D. Thamrin, "Form and Meaning of Batak Toba House Ornaments". Advanced Science Letters, vol. 22,

No. 12, pp.4050-4053, 2016.

[4] S.P. Napitupulu, Arsitektur Tradisional Daerah Sumatera Utara. Jakarta: Departemen Pendidikan dan Kebudayaan, 1997.

[5] S. Germain \& B. van der Goes, "Arsitektur Batak, Sumatera", in

Indonesian Heritage: Arsitektur, Gunawan Tjahjono, Ed. Jakarta: Grolier International, Inc., 2002.

[6] P. Widodo, Mengungkap Estetika Tersembunyi pada Bangunan Tradisional Batak untuk Menemukan Sistem Perbandingan Ukuran. Bandung: ITB, 2006.

[7] H. Hanan, "Modernization and Cultural Transformation: The Expansion of Traditional Batak House in Huta Siallagan". Journal

Procedia-Social and Behavioral Science, vol. 50, pp.800811, 2012.

[8] E. Panofsky, Meaning in the Visual Arts. Chicago: The University of Chicago Press, 1955.

[9] T.M. Sihombing, Filsafat Batak. Jakarta: Balai Pustaka, 2000. 